\title{
Effects of indolebutyric acid, stem cutting positions and substrates on the vegetative propagation of Stevia rebaudiana Bertoni
}

\section{Efectos de ácido indolbutírico, posiciones de estacas de tallo y sustratos sobre la propagación vegetativa de Stevia rebaudiana Bertoni}

GUILHERME BORTOLOSO PIGATTO'

ERIK NUNES GOMES 1,2

JÉSSICA DE CÁSSIA TOMASI'

AUREA PORTES FERRIANI'

CÍCERO DESCHAMPS

Branch, stem and leaf cutting of Stevia

rebaudiana Bertoni.

Photo: E.N. Gomes

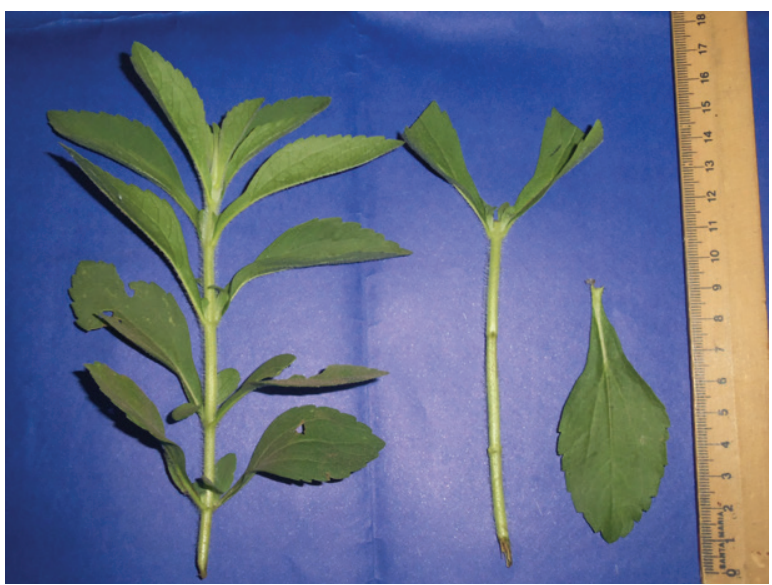

\begin{abstract}
Stevia rebaudiana Bertoni is a species with high economic importance because of the production of natural sweeteners with a low caloric value. The seed production of this species is irregular and micropropagation techniques raise the cost of seedling production. Thus, this study aimed to optimize the vegetative propagation of a Brazilian accession of this species through stem cuttings. The plant material was collected from one-year-old mature plants. Two experiments were carried out to determine the best indolebutyric acid (IBA) concentration to improve rooting and to evaluate the interaction between the stem cutting position (apical, medium and basal) and substrates (Tropstrato $\mathrm{HT}^{\circledR}$, vermiculite, and vermiculite/Tropstrato $\mathrm{HT}^{\circledR}$ mixture). The rooting of the stem cuttings was affected by the IBA concentrations. The application of $710 \mathrm{mg} \mathrm{L}^{-1} \mathrm{was}$ recommended for higher rooting percentages. The stem cuttings from the apical branch region had higher rooting percentages than the medium and basal areas (means of 70, 45.8 and 7.5\%, respectively). Similar results were observed for the root numbers, root lengths and root fresh and dry mass. The substrate Tropstrato $\mathrm{HT}^{\circledR}$ promoted higher rooting percentages and lower mortality than vermiculite.
\end{abstract}

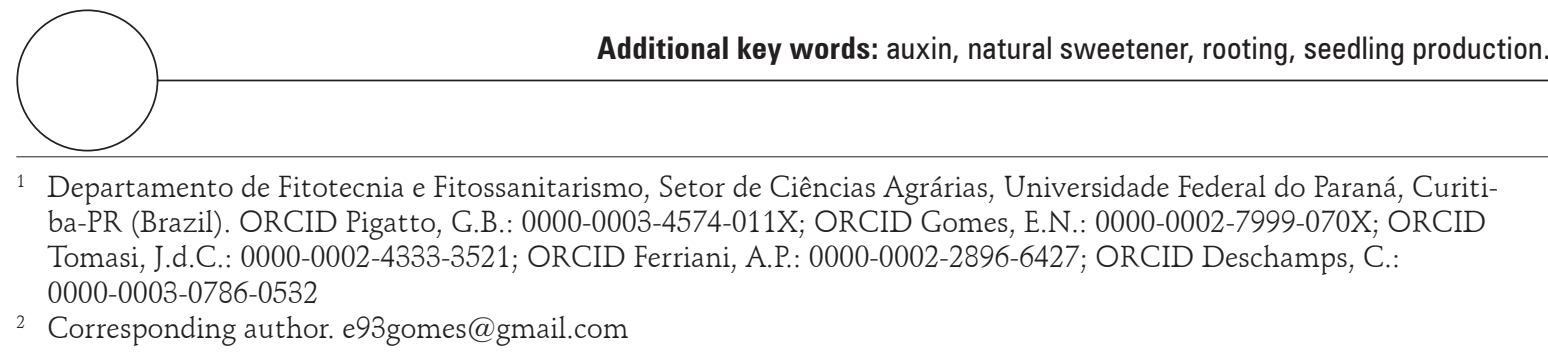




\section{RESUMEN}

Stevia rebaudiana Bertoni es una especie de alta importancia económica debido a la producción de edulcorantes naturales con bajo valor calórico. La producción de semillas de esta especie es irregular y las técnicas de micropropagación aumentan el costo de la producción de plántulas. Por lo tanto, este trabajo tuvo como objetivo optimizar la propagación vegetativa de un genotipo brasileño de esta especie a través de estacas de tallo. El material vegetal se recogió de plantas maduras con 1 año de edad. Se realizaron dos experimentos para determinar la mejor concentración de ácido indolbutírico (IBA) para mejorar el enraizamiento y evaluar la interacción entre la posición de corte del tallo (apical, mediana y basal) y sustratos (Tropstrato HT ${ }^{\circledR}$, vermiculita y mezcla de vermiculita y Tropstrato $\mathrm{HT}^{\circledR}$ ). Las estacas de tallos se vieron afectadas por las concentraciones de IBA. Se recomienda la aplicación de $710 \mathrm{mg} \mathrm{L}^{-1}$ de IBA para mayores porcentajes de enraizamiento. Las estacas de tallos de la región apical de las plantas mostraron mayor porcentaje de enraizamiento que las medianas y basales (medias de 70, 45,8 y 7,5\%, respectivamente). Se observaron resultados similares para el número, longitud y masa de raíz fresca y seca. El sustrato Tropstrato $\mathrm{HT}^{\circledR}$ promovió mayores porcentajes de enraizamiento de las estacas de tallo y menor mortalidad en comparación con la vermiculita.

Palabras clave adicionales: auxina, edulcorante natural, enraizamiento, producción de plántulas.

Received for publication: 25-06-2017 Accepted for publication: 30-01-2018

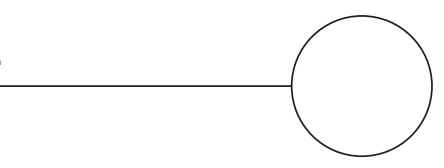

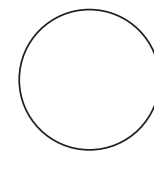

Popularly known as stevia, Stevia rebaudiana Bertoni is an herbaceous plant of the Asteraceae family. This plant is native to the Amambai mountain range on the border between Paraguay and Brazil (Lima Filho et al., 2004). The main interest in the cultivation of this species is the production of diterpene glycosides from its leaves. These compounds, also known as steviol glycosides, have a high sweetening potential together with a low calorific value (Ramesh et al., 2007; Saad et al., 2014; Jarma et al., 2010).

At least eight forms of steviol glycosides are known, with stevioside and rebaudioside-A being the most important to the industry. These substances are considered to be 300 to 400 times sweeter than sucrose, respectively (Lemus-Mondaca et al., 2012; Mandal et al., 2013). For industrial processing purposes, a higher concentration of rebaudioside-A over stevioside is desired because the latter has a strong bitter residual taste, a characteristic not appreciated by the market (Yadav et al., 2011).

In addition to the sweetening potential, this species also presents hypoglycemic action, improving pancreatic function, with antihypertensive, anti-inflammatory, antitumor, antioxidant, antidiarrheal, diuretic and immunomodulatory activities (Chatsudthipong and Muanprasat, 2009). In Brazil, its cultivation is still incipient, with imports of more than US\$8 million registered in 2013 (Brasil, 2014). One of the main difficulties encountered in the cultivation of this crop is the absence of genetic materials adapted to different climatic conditions (Yadav et al., 2011).

In addition to the lack of adapted genetic materials, adequate propagation techniques are also a limiting factor. Sexual propagation presents a series of drawbacks, such as the reduced seed size, low germination percentages rates and high sensitivity to biotic stress (Goettemoeller and Ching 1999; Yadav et al., 2011). Techniques for micropropagation are already standardized and effective; however, the high cost of this method is an obstacle (Sivaram and Mukundam 2003; Khalil et al., 2014). Clonal propagation through stem cuttings represents a potential alternative for propagation of the species, but still requires additional studies in order to achieve reasonable rooting percentages (De Carvalho and Zaidan, 1995; Kassahun and Mekonnen, 2011; LeCroy, 2014; Patel, 2015).

Many factors affect the adventitious rooting of stem cuttings; endogenous hormone concentration, plant regulators, juvenility, seasonality and environmental conditions during rooting are the most important (Hartmann et al., 2010). 
For environmental conditions, the use of a suitable substrate that improves root growth and development is desirable. It must have characteristics such as adequate porosity, drainage, homogeneity, absence of pathogens, and economic viability (Mendes et al., 2014).

The position of the stem cuttings in the branches also affects rooting since it interferes with hormonal and juvenile issues. Apical cuttings have higher rates of auxin synthesis and may be less tissue differentiated, but they are more sensitive to dehydration. Basal stem cuttings, in spite of the lower levels of endogenous auxin, have a greater capacity to provide the necessary reserves for the formation and growth of roots and shoots (Cunha et al., 2015).

The exogenous application of plant regulators, especially auxins, has been used in several species of interest, resulting in increased rooting percentages and root system development, with a greater root number, vigor and uniformity and reduction of the period for root emission (Tracz et al., 2014). Among the auxins, indolebutyric acid (IBA) is one of the most used since it is a photostable compound, non-toxic and has low rates of degradation by biological action (Paulus et al., 2014).

The objective of this study was to evaluate the influence of the stem cutting position, substrate and IBA concentrations on the rooting of an accession of S. rebaudiana adapted for cultivation in Parana State, Brazil.

\section{MATERIAL AND METHODS}

The stem cuttings were collected in September, 2015, from one-year-old plants (clones) grown in the Medicinal and Aromatic Plants Research Area of the Federal University of Parana (Brazil) at the following coordinates: $25^{\circ} 23^{\prime} 30$ "S and $49^{\circ} 07^{\prime} 30^{\prime \prime} \mathrm{W}$, with an altitude of $930 \mathrm{~m}$ a.s.1.

The evaluated plant accession was provided by the "Genetic Resources and Biotechnology Centre - CENARGEN" of the Brazilian Agricultural Research Corporation - EMBRAPA. In a previous evaluation of the productive potential of this accession in Parana State, a dry mass yield of leaves higher than $3,000 \mathrm{~kg}$ $\mathrm{ha}^{-1}$ with stevioside and rebaudioside-A contents of 13.4 and $6.9 \%$, respectively, and high frost tolerance were observed (unpublished data).
Stem cuttings were made with a length between 10 and $12 \mathrm{~cm}$ with one pair of leaves and the leaf area reduced by half. Before planting, the stem cuttings were submitted to phytosanitary treatment with $0.5 \%(\mathrm{v} / \mathrm{v})$ sodium hypochlorite for $15 \mathrm{~min}$, followed by washing in running water for $5 \mathrm{~min}$.

Two experiments were carried out in order to evaluate better conditions for promoting the rhizogenic potential of this accession. The first experiment compared the rooting of non-treated cuttings and cuttings treated with IBA (Vetec ${ }^{\circledast}, 98 \%$ purity) concentrations $\left(250 ; 500 ; 1,000\right.$ or $\left.2,000 \mathrm{mg} \mathrm{L}^{-1}\right)$ in a completely randomized design with 5 treatments and 4 replicates, each one with 10 stem cuttings. The base of the stem cuttings were immersed for $15 \mathrm{sec}$ in the IBA solutions and then placed in tubes filled with the commercial substrate Tropstrato $\mathrm{HT}^{\circledR}$ for rooting.

The second experiment compared the stem cutting positions (apical, medium and basal) in the branches and substrates on the development of the root system. The evaluated substrates were Tropstrato HT $^{\circledR}$ (Vida Verde - Tecnologia em Substratos ${ }^{\mathrm{TM}}$, Brazil) commercial substrate (TROP), fine granulometry vermiculite (VERM) and a mixture of 50\% Tropstrato $\mathrm{HT}^{\circledR}$ commercial substrate and $50 \%$ vermiculite (MIX). According to the manufacturer information, the Tropstrato $\mathrm{HT}^{\oplus}$ commercial substrate is composed of pine bark, peat, expanded vermiculite, enriched with macro and micronutrients, with a $\mathrm{pH}$ of 5.8 and density in dry basis of $200 \mathrm{~kg} \mathrm{~m}^{-3}$. The experiment design was completely randomized in a $3 \times 3$ factorial arrangement, comparing the stem cutting positions and substrates with 4 replicates, each one with 10 stem cuttings.

For both experiments, the cuttings were planted in $120 \mathrm{~cm}^{3}$ polypropylene tubes and kept in a greenhouse with intermittent mist of $5 \mathrm{~s}$ every $30 \mathrm{~min}$. The relative humidity in the greenhouse was around $80 \%$ and the temperature varied between 20 and $30^{\circ} \mathrm{C}$ during the experiment period.

Thirty days after planting, the stem cuttings were evaluated for the rooting percentage (considering the number of live cuttings with roots of at least $1 \mathrm{~mm}$ in length in relation to the number of planted cuttings in each replicate), mortality (considering the relative amount of cuttings with all of the tissues necrotic), sprouting percentage (calculated with the number of cuttings with formation of new sprouts) and average number, length and dry mass of roots. 
The length of the roots was measured with a graduated ruler and the result was the arithmetic mean of the three longer roots lengths in each cutting within the replicate. The dry mass of the roots was obtained by drying the fresh material in a forced circulation air oven at $65^{\circ} \mathrm{C}$ until constant weight. The dried roots were weighed on an analytical precision scale $(0.0001 \mathrm{~g})$.

The data were submitted to analysis of variances homogeneity with Bartlett's test. For the experiment with cutting positions and substrates, the means were compared with Tukey's Test at $5 \%$ probability. For the experiment with different IBA concentrations, polynomial regression analysis was performed. For all analyses, the statistical software Assistat (Silva and Azevedo, 2016) was used.

\section{RESULTS AND DISCUSSION}

Rooting percentages ranging from 2.5 to $32.5 \%$ were observed after the stem cutting treatment with indolebutyric acid. The response of this variable to the plant growth regulator concentrations was quadratic, with a maximum technical efficiency concentration of $710 \mathrm{mg} \mathrm{L}^{-1}$, calculated with the regression equation (Fig. 1A).

The adventitious rhizogenesis in the stem cuttings was strongly influenced by auxins, and, in plants of commercial interest, this process is greatly enhanced by the exogenous supplementation of synthetic auxins (Zuffellato-Ribas and Rodrigues, 2001). The application of plant growth regulators at an optimal concentration stimulates the growth and differentiation of the tissues, causing an increase in the percentage of rooting, which will also be dependent on the endogenous level of hormones and other rooting promoters (Hartmann et al., 2010).

The application of auxin increased the rooting percentages; however, there was a marked decrease in the rooting when the stem cuttings were treated with $2,000 \mathrm{mg} \mathrm{L}^{-1}$ of IBA. Similar results were obtained by Smitha and Umesha (2012), where a higher percentage of rooting was reported in stevia stem cuttings treated with IBA $500 \mathrm{mg} \mathrm{L}^{-1}$ and $1,000 \mathrm{mg} \mathrm{L}^{-1}$ , as compared to the control treatment and concentration of 2,000 $\mathrm{mg} \mathrm{L}^{-1}$. The reduction in the rooting, sprouting, number, length and dry mass of roots, as well as a significant increase in mortality rates (Fig. 1) at higher concentrations of IBA may be related to a phytotoxicity effect since excessive concentrations of auxins may inhibit the development of roots and shoots, causing yellowing and leaf abscission, necrosis and even death of stem cuttings (Alcantara et al., 2010).

Compared to other studies on stevia propagation with stem cuttings (De Carvalho and Zaidan 1995; Kassahun and Mekonnen, 2011; Smitha and Umesha 2012; Khalil et al., 2014), a higher mortality and significantly lower rooting percentages were found under these experiment conditions.

In addition to the genetic variations observed among cultivars or accessions, the physiological condition of plants can result in differences in survival and rooting potential. Seasonality is considered one of the main factors affecting the physiological condition of plants. In a study evaluating the seasonality effect on the rooting of stevia stem cuttings, De Carvalho and Zaidan (1995) found reduced rooting percentages in October (mean of $5.75 \%$ ), as compared to May and July (means of 44.3 and $40.6 \%$, respectively). The authors attributed the low rates of rooting in October to the synthesis of hormones related to reproductive aspects that can inhibit or compete with the action of auxins in the process of adventitious rooting induction. In addition to the effects of seasonality, the physiological condition affected by the collection position of the stem cuttings in the parent plants may influence rhizogenesis.

The maximum sprouting percentage was observed at the concentration of $542.5 \mathrm{mg} \mathrm{L}^{-1}$ of IBA (Fig. 1C). The fact that the maximum efficiency of sprouting was lower than that observed for rooting may be associated with the fact that the synthetic auxin mobilized nutrients for root formation, inhibiting sprouting when applied at the base of the cutting (Magevski et al., 2011), so, when the better conditions to rooting were provided, some reduction in sprouting was observed.

The root number and length were also affected by IBA treatments, reaching maximum values estimated at concentrations of 1,250 and $700 \mathrm{mg} \mathrm{L}^{-1}$ of IBA by the second-degree polynomial equations, respectively (Figs. 1D and E).

In comparison with other studies on $S$. rebaudiana, the maximum efficient concentration for the number of roots was high. Koppad et al. (2006) reported a higher average number of roots at $35 \mathrm{~d}$ after implantation 
with stem cuttings treated with $500 \mathrm{mg} \mathrm{L}^{-1}$ of IBA. Similarly, Khalil et al. (2014) reported higher values with immersion of cuttings in an IBA solution at 500 $\mathrm{mg} \mathrm{L}^{-1}$. In an experiment conducted in Malaysia with two commercial cultivars of stevia, greater increases were observed in the number of roots with an IBA concentration of 426, $8 \mathrm{mg} \mathrm{L}^{-1}$ for the cultivar MS012 and $499.9 \mathrm{mg} \mathrm{L}^{-1}$ for cultivar MS007, evidencing the
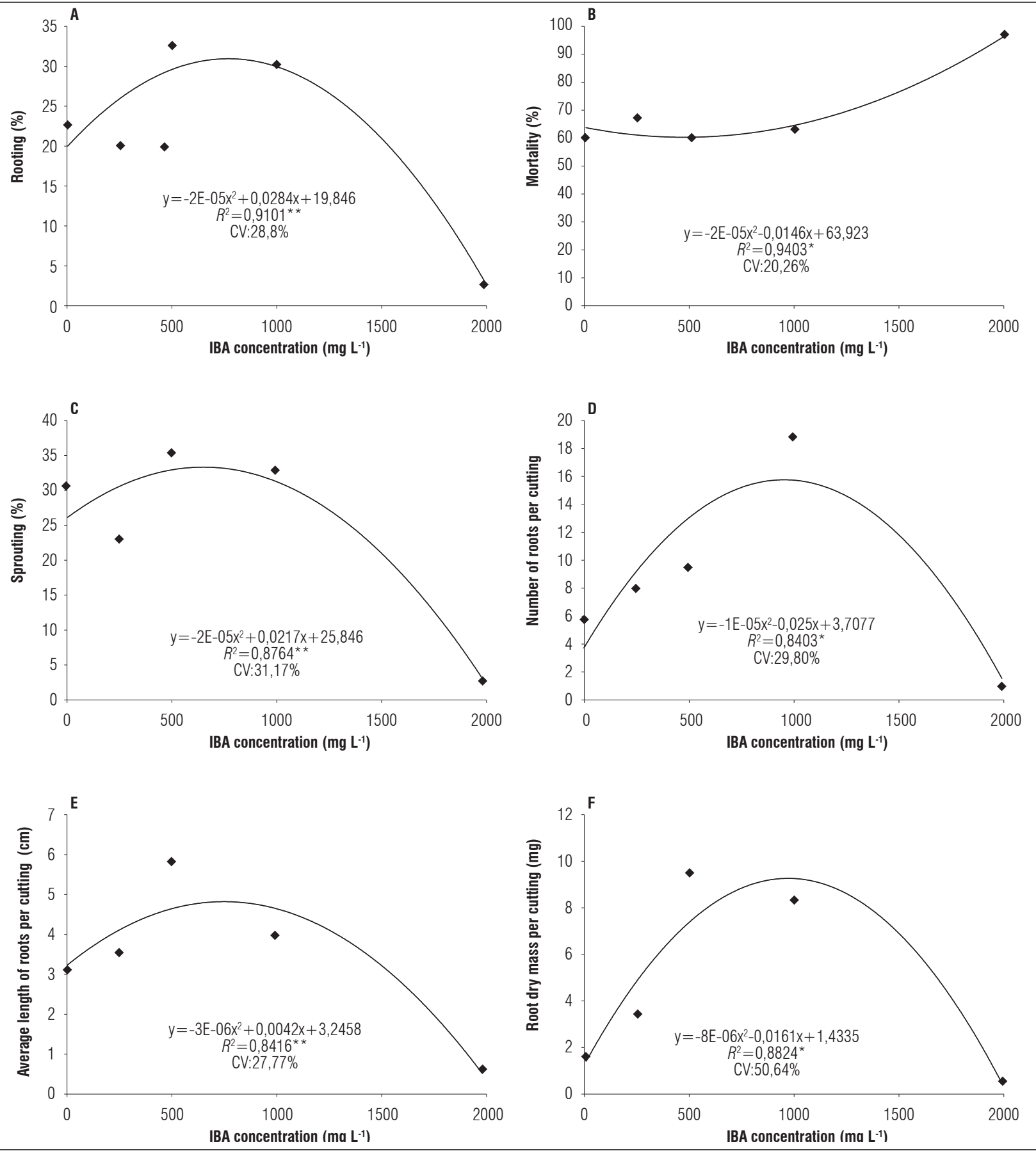

Figure 1. A. Rooting; B. Mortality; C. Sprouting percentages; D. Number; E. Average length; F. Dry mass of roots in Stevia rebaudiana Bertoni (Accession 8 ) stem cuttings treated with different indolebutyric acid (IBA) concentrations. ** Significant at $1 \%$ probability according to polynomial regression analysis. * Significant at $5 \%$ probability according to polynomial regression analysis. CV: coefficient of variation. 
difference in response between genetic materials (Abdullateef and Osman, 2011).

Genetic interference in the responses of each cultivar or accession to a regulator application is the most probable cause of the observed difference in the present experiment in relation to those previous mentioned in the literature. It strongly justifies the need for studies on specific accessions or cultivars in order to improve the vegetative propagation of potential genetic materials.

For the average root length, the response to the plant growth regulator was closer to that reported by some authors who reported optimal concentrations of 500 mg L-1 of IBA (Koppad et al., 2006; Smitha and Umesha 2012; Khalil et al., 2014). Medina et al. (2016) also reported positive effects of IBA applications on root lengths for stevia cuttings. The increase in the number and length of roots of stevia stem cuttings submitted to auxin treatment may be related to a increase in the sensitivity of the basal tissue of the cutting, as well as to an improvement in the capacity for hydrolysis of reserves, necessary for root development (Osman et al., 2013).

The root dry mass was also affected by the application of IBA, with the maximum value estimated at $1,006.25 \mathrm{mg} \mathrm{L}^{-1}$. In a study reported by Khalil et al. (2014) with stevia stem cuttings in Pakistan, the fresh mass of roots treated with $500 \mathrm{mg} \mathrm{L}^{-1}$ and 1,000 $\mathrm{mg} \mathrm{L}^{-1}$ concentrations did not differ statistically, with the dry mass for the concentration of $1,000 \mathrm{mg} \mathrm{L}^{-1}$ being higher, similar to the present study. Different results, however, were reported by Smitha and Umesha
(2012), where a higher root dry mass was obtained with cuttings treated with $2,000 \mathrm{mg} \mathrm{L}^{-1}$ of IBA.

For the experiment on substrates and stem cutting positions, a significant interaction was found for root length and root dry mass (Tab. 1). Evaluating the factors alone, the type of substrate influenced all analyzed variables, except the sprouting percentage. The type of cutting was the factor that exerted the greatest influence on the rooting of accession 8 , being significant for all observed variables. The apical stem cuttings presented a greater rooting than the median ones, which, in turn, performed better than the basal stem cuttings. For the substrates, Tropstrato $\mathrm{HT}^{\oplus}$ promoted higher percentages in comparison to vermiculite (Tab. 2).

The highest percentages of rooting, observed in the apical stem cuttings, can be related to a low level of phenolic compounds at these locations and the fact that hormones (mainly auxins) and cofactors that act in rooting are in higher concentrations at the apex of branches (Fachinello et al., 1995; Hartmann et al., 2010).

Smitha and Umesha (2012) evaluated the rooting of stevia basal stem cuttings in different substrates, rooting environments and plant regulators in southern India. Among the substrates evaluated, a higher percentage of rooting $(79.7 \%)$ was observed in a mixture of soil, sand and coconut shell powder at a ratio of 1:1:1. The lowest rooting percentage was $67 \%$ in a mixture of soil, sand and manure in equal proportions, which was even superior to the means observed in the present experiment for basal

Table 1. Summary of the analysis of variance (ANOVA) for the variables percentage of rooting (ROT), mortality (MRT), sprouting (SPT) number of roots per cutting (NRC), average length of roots per cutting (LRC) and roots dry mass per cutting (RDM) of apical, medium and basal stem cuttings of Stevia rebaudiana Bertoni (Accession 8) planted in three substrates: Tropstrato $\mathbf{H T}^{\circledR}$, vermiculite and mixture (50\% Tropstrato $\mathbf{H T}^{\circledR}$ and $\mathbf{5 0} \%$ vermiculite).

\begin{tabular}{|l|c|c|c|c|c|c|c|}
\hline \multirow{2}{*}{\begin{tabular}{c}
\multirow{2}{*}{$\begin{array}{c}\text { Source of } \\
\text { variation }\end{array}$} \\
\cline { 3 - 8 }
\end{tabular}} & \multirow{2}{*}{ D.F. } & ROT & MRT & SPT & NRC & LRC & RDM \\
\hline Substrates & 2 & $677,8^{* *}$ & $436,1^{*}$ & $97,7^{\text {ns }}$ & $3,0^{*}$ & $12,5^{*}$ & $515,1^{* *}$ \\
\hline Types of cuttings & 2 & $11586,1^{* *}$ & $11136,1^{* *}$ & $3167,2^{* *}$ & $48,9^{* *}$ & $81,7^{* *}$ & $5610,5^{* *}$ \\
\hline Interaction & 4 & $106,9^{\text {ns }}$ & $27,8^{\text {ns }}$ & $76,9^{\text {ns }}$ & $2,1^{\text {ns }}$ & $20,0^{* *}$ & $260,7^{*}$ \\
\hline Error & 27 & 97,2 & 110,2 & 48,4 & 0,8 & 3,7 & 70,3 \\
\hline C.V. (\%) & & 23,82 & 19,58 & 30,12 & 41,73 & 34,12 & 37,56 \\
\hline
\end{tabular}

D.F.: Degree of freedom; ${ }^{*}$ Significant at $1 \%$ probability; ${ }^{*}$ Significant at $5 \%$ probability; ns: Not significant at $1 \%$ and $5 \%$ probability. C.V.: coefficient of variation. 
Table 2. Means of rooting, mortality and sprouting percentages, number of roots per cutting, average length of roots and roots dry mass in Stevia rebaudiana Bertoni (Accession 8) stem cuttings planted in different substrates.

\begin{tabular}{|c|c|c|c|c|}
\hline \multirow{3}{*}{ Substrates } & \multicolumn{3}{|c|}{ Type of stem cutting } & \multirow{3}{*}{ Mean } \\
\hline & Apical & Medium & Basal & \\
\hline & \multicolumn{3}{|c|}{ Rooting (\%) } & \\
\hline Vermiculite & 67,50 & 32,50 & 2,50 & $34,17 \mathrm{~b}$ \\
\hline Tropstrato $\mathrm{HT}^{\circledR}$ & 77,50 & 55,00 & 15,00 & 49,17 a \\
\hline \multirow[t]{2}{*}{$\begin{array}{l}\text { Mixture } \\
\text { Mean }\end{array}$} & $\begin{array}{l}65,00 \\
70,00 \mathrm{~A}\end{array}$ & $\begin{array}{l}50,00 \\
45,83 \text { B }\end{array}$ & $\begin{array}{l}7,50 \\
8,33 \mathrm{C}\end{array}$ & $40,83 a b$ \\
\hline & \multicolumn{3}{|c|}{ Mortality (\%) } & \\
\hline Vermiculite & 30,00 & 52,50 & 90,00 & 57,50 a \\
\hline Tropstrato $\mathrm{HT}^{\circledR}$ & 17,50 & 42,50 & 80,00 & $46,67 b$ \\
\hline \multirow[t]{2}{*}{$\begin{array}{l}\text { Mixture } \\
\text { Mean }\end{array}$} & $\begin{array}{l}32,50 \\
26,67 \mathrm{C}\end{array}$ & $\begin{array}{l}47,50 \\
47,50 \mathrm{~B}\end{array}$ & $\begin{array}{l}90,00 \\
86,66 \mathrm{~A}\end{array}$ & 56,67 a \\
\hline & \multicolumn{3}{|c|}{ Sprouting (\%) } & \\
\hline Vermiculite & 17,50 & 42,50 & 10,00 & $23,33^{\text {ns }}$ \\
\hline Tropstrato $\mathrm{HT}^{\circledR}$ & 12,50 & 45,00 & 20,00 & 25,83 \\
\hline \multirow[t]{2}{*}{$\begin{array}{l}\text { Mixture } \\
\text { Mean }\end{array}$} & $\begin{array}{l}15,00 \\
15,00 \text { B }\end{array}$ & $\begin{array}{l}37,92 \\
41,81 \mathrm{~A}\end{array}$ & $\begin{array}{c}7,50 \\
12,50 \text { B }\end{array}$ & 20,14 \\
\hline & \multicolumn{3}{|c|}{ Number of roots per cutting } & \\
\hline Vermiculite & 3,35 & 1,78 & 0,28 & $1,80 \mathrm{~b}$ \\
\hline Tropstrato $\mathrm{HT}^{\circledR}$ & 5,88 & 2,03 & 0,35 & $2,75 a$ \\
\hline \multirow[t]{2}{*}{$\begin{array}{l}\text { Mixture } \\
\text { Mean }\end{array}$} & $\begin{array}{l}3,85 \\
4,35 \mathrm{~A}\end{array}$ & $\begin{array}{l}1,70 \\
1,83 \mathrm{~B}\end{array}$ & $\begin{array}{l}0,48 \\
0,37 \mathrm{C}\end{array}$ & $2,01 a b$ \\
\hline & \multicolumn{3}{|c|}{ Average length of roots per cutting $(\mathrm{cm})$} & \\
\hline Vermiculite & 7,46 aA & $7,41 \mathrm{aA}$ & $0,20 \mathrm{bB}$ & 5,02 \\
\hline Tropstrato $\mathrm{HT}^{\circledR}$ & 9,99 aA & $6,49 \mathrm{abB}$ & $4,02 \mathrm{aB}$ & 6,83 \\
\hline \multirow[t]{2}{*}{$\begin{array}{l}\text { Mixture } \\
\text { Mean }\end{array}$} & $\begin{array}{l}7,23 \text { aA } \\
8,22\end{array}$ & $\begin{array}{l}3,27 \text { bB } \\
5,72\end{array}$ & $\begin{array}{l}4,81 \text { aAB } \\
3,01\end{array}$ & 5,10 \\
\hline & \multicolumn{3}{|c|}{ Root dry mass per cutting (mg) } & \\
\hline Vermiculite & $39,60 \mathrm{bA}$ & $14,87 \mathrm{aB}$ & $0,23 \mathrm{aB}$ & 18,23 \\
\hline Tropstrato $\mathrm{HT}^{\circledR}$ & 63,68 aA & $20,90 \mathrm{aB}$ & $5,08 \mathrm{aC}$ & 29,88 \\
\hline $\begin{array}{l}\text { Mixture } \\
\text { Mean }\end{array}$ & $\begin{array}{l}34,67 \text { bA } \\
45,98\end{array}$ & $\begin{array}{l}16,50 \mathrm{aB} \\
17,42\end{array}$ & $\begin{array}{l}5,43 \mathrm{aB} \\
3,58\end{array}$ & 18,87 \\
\hline
\end{tabular}

Means followed by the same capital letter in the rows and lowercase in the columns do not differ by the Tukey's test $(P \leq 0.05)$. ns: not significant.

cuttings. This indicates that not just the substrate and type of stem cutting exert influence on rooting. The genetic differences of the plant material and the time of year in which the cuttings are collected can also be determinant of the rhizogenic process (Zuffellato-Ribas and Rodrigues, 2001).

Bona et al. (2005) compared five substrates (soil, sand, vermiculite, charcoal rice husk and commercial substrate Plantmax $\left.{ }^{\circledR}\right)$ in the rooting of median stem cuttings of plants of the genus Baccharis (Asteraceae). Similar to the present study, there was a significant difference between the substrates, the commercial substrate being superior in two of the three species analyzed for the rooting percentage.

According to Hartmann et al. (2010) the ideal substrate would allow high aeration and water retention capacity and, at the same time, be well-drained and free of pathogens. In this sense, it can be confirmed 
that the commercial substrate Tropstrato $\mathrm{HT}^{\circledR}$, as well as being a source of nutrients, also showed suitable physical characteristics for rooting stevia stem cuttings. The results also showed that mixing with inert materials, such as vermiculite, is not necessary for rooting this stevia accession.

For the mortality percentage of the stem cuttings, higher values occurred in the basal cuttings (86.66\%). Considering the substrates, the vermiculite and the vermiculite and Tropstrato $\mathrm{HT}^{\circledR}$ mixture presented the highest values. Garbuio et al. (2007), evaluating apical, median and basal patchouli (Pogostemon cablin) stem cuttings, reported lower mortalities for basal cuttings, different from that observed for the stevia cuttings in the present study. According to these authors, basal cuttings have greater resistance to dehydration; however, they presented low rooting percentages, not justifying their use.

For the sprouting percentage, the medium cuttings had the highest values in comparison with the apical and basal ones, which can be related to the higher mortality of the basal cuttings, as well as to the fact that apical cuttings have a greater allocation of reserves for rooting rather than sprouting. It is possible that the superiority in the percentage of sprouting in the median stem cuttings in relation to the apical ones was due to the smaller rooting capacity. Bischoff et al. (2017); similarly, the low rooting capacity of black sage (Varronia curassavica Jacq.) stem cuttings was attributed to the high sprouting percentages observed since, according to the authors, most of the reserves present in the stem were translocated for shoot formation rather than for roots.

The average number of roots per cutting, similar to the responses observed for rooting percentages, was higher in the apical cuttings, followed by the median and basal ones. The apical stem cuttings of Lavandula dentata L. also presented a greater number and length of roots than the basal ones (Bona et al., 2012), corroborating with the results of the present study.

For the effect of substrates, the number of roots was higher in the Tropstrato $\mathrm{HT}^{\circledR}$ commercial substrate than in the vermiculite. For the average length and dry mass of roots, a similar behavior was observed, with higher values in the apical cuttings planted in Tropstrato $\mathrm{HT}^{\circledR}$ and very low values in the basal cuttings planted in tubes containing vermiculite.
The main aspect that differentiated the substrates used in the present experiment was the availability of nutrients since vermiculite is an inert substrate. The availability of nutrients, although not a fundamental characteristic for rooting stem cuttings, is an important factor for the early development of seedlings (Amaro et al., 2013). For stevia, Smitha and Umesha (2012) reported a higher number of roots per cutting in substrates with higher nutrient contents, in detriment of other substrates such as soil and sand. In Piper amalago stem cuttings, Nunes Gomes and Krinski (2016) similarly reported that the substrate with a greater availability of nutrients promoted the highest values of number, length and fresh mass of roots.

Based on the results obtained in the present work, it is possible to affirm that the supply of suitable mesological characteristics (substrates) can potentiate favorable endogenous conditions for rooting stem cuttings of the studied acession, and the association of apical cuttings and the commercial substrate Tropstrato $\mathrm{HT}^{\circledR}$ is recommended for the production of seedlings with higher quality.

\section{CONCLUSIONS}

The evaluated stevia accession had a capacity for adventitious rhizogenesis and initial development of root system that was influenced by the application of the indolebutyric acid. The application of $710 \mathrm{mg}$ $\mathrm{L}^{-1}$ is recommended for higher rooting percentages.

The position in the plant from where the stem cuttings are collected affects the rooting of Stevia rebaudiana. Cuttings collected from the apical segment are more indicated for the evaluated accession. For higher values of rooting and number of roots, as well as lower mortality values, the commercial substrate Tropstrato $\mathrm{HT}^{\circledR}$ is the most suitable for the rooting of the evaluated genotype.

\section{ACKNOWLEDGMENTS}

This research was funded by the Brazilian Coordination for the Improvement of Higher Education Personnel (CAPES) and the Federal University of Parana. The authors would like to acknowledge the Brazilian company of agricultural research division of genetic resources and biotechnology (EMBRAPA-CENARGEN) for providing the genetic material. 
Conflict of interests: the manuscript was prepared and reviewed with the participation of the authors, who declare that there exists no conflict of interest that puts in risk the validity of the presented results.

\section{BIBLIOGRAPHIC REFERENCES}

Abdullateef, R.A. and M. Osman. 2012. Effects of stem cutting types, position and hormonal factors on rooting in Stevia rebaudiana Bertoni. J. Agr. Sci. 4(1), 49-57. Doi: $10.5539 /$ jas.v4n1p49

Alcantara, G.B., Y. Oliveira, D.M. Lima, L.A. Fogaça, F. Pinto, and L.A. Biasi. 2010. Efeito dos ácidos naftaleno acético e indolilbutírico no enraizamento de estacas de jambolão [Syzygium cumini (L.) Skeels]. Rev. Bras. Plantas Med. 12(3), 317-321. Doi: 10.1590/ S1516-05722010000300009

Amaro, H.T.R, J.R. Silveira, A.M.S.S. David, M.A.V. Resende, and J.A.S. Andrade. 2013. Tipos de estacas e substratos na propagação vegetativa da menta (Mentha arvensis L.). Revista Rev. Bras. Plantas Med. 15(3), 313-318. Doi: 10.1590/S1516-05722013000300001

Bischoff, A., D. Vendramim, E. Nunes Gomes, K.C. Zuffellato-Ribas, M.L. Engel, and R.A. Maggioni. 2017. Enraizamento de estacas de erva-baleeira em função de diferentes concentrações de ácido indol butírico e número de folhas. Rev. Ciênc. Agroveterinárias 16(1), 41-47. Doi: 10.5965/223811711612017041

Bona, C.M., I.R. Biasetto, M. Masetto, C. Deschamps, and L.A. Biasi. 2012. Influence of cutting type and size on rooting of Lavandula dentata L. Rev. Bras. Plantas Med. 14(1), 8-11. Doi: 10.1590/ S1516-05722012000100002

Bona, C.M., L.A., F. Zanette, and T. Nakashima. 2005. Estaquia de três espécies de Baccharis. Cienc. Rural. 35 (1), 223-226. Doi: /10.1590/S0103-84782005000100037

Brasil (Ministério do Desenvolvimento, Indústria e Comércio Exterior). Secretaria do Comércio Exterior. 2014. Programa AliceWeb. 2014. In: http://aliceweb.desenvolvimento.gov.br; consulted: May 26, 2014.

Chatsudthipong, V. and C. Muanprasat. 2009. Stevioside and related compounds: Therapeutic benefits beyond sweetness. Pharmacol. Ther. 121(1), 41-54. Doi: 10.1016/j.pharmthera.2008.09.007

Cunha, A., F. Chaves, A. Batista, and A. Hidalgo. 2015. Propagação vegetativa de estacas de Piper hispidum Sw. em diferentes substratos. Rev. Bras. Plantas Med. 17(4), 685-692. Doi: 10.1590/1983-084X/14_113

De Carvalho, M.A.M. and L.B.P. Zaidan. 1995. Obtenção de estacas de Stevia rebaudiana através de estacas. Pesq. Agropec. Bras. 30(2), 201-206.
Fachinello, J. C., A. Hoffmann, J. C. Nachtigal, E. Kersten, and G.R.L. Fortes. 1995. Propagação de plantas frutíferas de clima temperado. $2^{\text {nd }}$ ed. Editora UFPEL, Pelotas-RS, Brazil.

Garbuio, C., L.A. Biasi, A. Kowalski, D. Signor, E. Machado, and C. Deschamps. 2007. Propagação por estaquia em patchouli com diferentes números de folhas e tipos de estacas. Sci. Agr. 8(4), 435-438. Doi: 10.5380/rsa. v8i4.9893

Goettemoeller, J. and A. Ching. 1999. Seed germination in Stevia rebaudiana. pp. 510-511. In: Janick, J. (ed.). Perspectives on new crops and new uses. ASHS Press, Alexandria, VA, USA.

Hartmann, H., D. Kester, F. Davies, and R. Geneve. 2010. Plant propagation. Principles and practices. $8^{\text {th }}$ ed. Prentice Hall, New Jersey, NJ, USA.

Jarma, A., M. Espitia, and G. Fischer. 2010. Síntesis de esteviósidos en estevia (Stevia rebaudiana Bert.). Acta Biol. Colomb. 15(1), 263-268.

Kassahun, B. M. and S.A. Mekonnen. 2011. Effect of cutting position and rooting hormone on propagation ability of stevia (Stevia rebaudiana Bertoni). J. Plant. Biochem. Biotechnol. 6(1), 5-8.

Khalil, S.A., R. Zamir, and N. Ahmad. 2014. Selection of suitable propagation method for consistent plantlets production in Stevia rebaudiana (Bertoni). Saudi. J. Biol. Sci. 21(6), 566-573. Doi: 10.1016/j.sjbs.2014.02.005

Koppad, A.G., N.K. Umarbadshah, and M. Gouda. 2006. Effect of growth regulators on propagation of stem cuttings in Stevia rebaudiana. Karnataka J. Agric. Sci. 19(3), 740-742.

LeCroy, J. 2014. Factors affecting seed and stem cutting propagation of Stevia rebaudiana (Bert.). M.Sc. thesis. Graduate Faculty, Auburn University, Auburn, AL, USA.

Lemus-Mondaca, R., A.Vega-Gálvez, L. Zura-Bravo, and K. Ah-Hen. 2012. Stevia rebaudiana Bertoni, source of a high-potency natural sweetener: A comprehensive review on the biochemical, nutritional and functional aspects. Food Chem. 132(3), 1121-1132. Doi: 10.1016/j.foodchem.2011.11.140

Lima Filho, O.F., A.C. Valois, and Z.M. Lucas. 2004. Sistemas de Produção 5: Estévia. Empresa Brasileira de Pesquisa Agropecuária (Embrapa) Agropecuária Oeste, Dourados-MS, Brazil.

Magevski, G.C., M.P. Czepak, E.R. Schmildt, R.S. Alexandre, and A.A. Fernandes. 2011. Propagação vegetativa de espécies silvestres do gênero Piper, com potencial para uso como porta enxertos em pimenta-do-reino (Piper nigrun). Rev. Bras. Plantas Med. 13(special), 559563. Doi: 10.1590/S1516-05722011000500009

Mandal, S., H. Evelina, B.B. Giri, V. P.Singha, and R. Kapoor. 2013. Arbuscular mycorrhiza enhances the production of stevioside and rebaudioside-A in Stevia 
rebaudiana via nutritional and non-nutritional mechanisms. Appl. Soil Ecol. 72(1), 187-194. Doi: 10.1016/j. apsoil.2013.07.003

Medina, E.L., A.E.G. Rivero, and A.L. Zavaleta. 2016. Enraizamiento de esquejes de Stevia rebaudiana Bertoni (Asteraceae) "estevia", aplicando dosis creciente de ácido indolbutírico. Arnaldoa, 23(2), 569-576. Doi: 10.22497/arnaldoa.232.23209

Mendes, A.D.R., T.H.S. Lacerda, S.M.G. Rocha, and E.R. Martins. 2014. Reguladores vegetais e substratos no enraizamento de estacas de erva-baleeira (Varronia curassavica Jacq.). Rev. Bras. Plantas Med. 16(2), 262270. Doi: 10.1590/S1516-05722014000200015

Nunes Gomes, E. and D. Krinski. 2016. Propagação vegetativa de Piper amalago L. (Piperaceae) em função de tipos de estaca e substratos. Cult. Agron. 25(3), 199-210.

Osman, M., N.S. Samsudin, G. Faruq, and A. Nezhadahmadi. 2013. Factors affecting microcuttings of Stevia using a mist-chamber propagation box. Sci. World J. 2013, 1-10. Doi: 10.1155/2013/940201

Patel, D.K. 2015. Stem cutting propagation for ex-situ conservation of Stevia rebaudiana (Bertoni) Bertoni in herbal garden. Eur. J. Biotechnol. 3(9), 35-42.

Paulus, D., R. Valmorbida, E. Toffoli, and E. Paulus. 2014. Propagação vegetativa de Aloysia triphylla (L'Hér.) Britton em função da concentração de AIB e do comprimento das estacas. Rev. Bras. Plantas Med.16(1), 25-31. Doi: 10.1590/S1516-05722014000100004
Ramesh, K., V. Singh, and P.S. Ahuja. 2007. Production potential of Stevia rebaudiana (Bert.) Bertoni. under intercropping systems. Arch. Agron. Soil Sci. 53(4), 443-458. Doi: 10.1080/03650340701474949

Saad, A., F.A. Khan, A. Hayee, and M.S. Nazir. 2014. A Review on Potential Toxicity of Artificial Sweetners vs Safety of Stevia: A Natural Bio-Sweetner. J. Biol. Agric. Healthc. 4(15) 137-145.

Silva, F.A.S. and C.A.V. Azevedo. 2016. Comparison of means of agricultural experimentation data through different tests using the software Assistat. Afr. J. Agric. Res. 37(11), 3527-3531. Doi: 10.5897/ AJAR2016.11523

Sivaram, L. and U. Mukundam. 2003. In vitro culture studies on Stevia rebaudiana. In Vitro Cell. Dev. Biol. 39(5), 520-523. Doi: 10.1079/IVP2003438

Smitha, G.R. and K. Umesha. 2012. Vegetative propagation of stevia [Stevia rebaudiana (Bertoni) Hems.] through cuttings. J. Trop. Agr. 50(1), 72-75.

Tracz, V., C.T.A. Cruz-Silva, and M.Z. Luz. 2014. Produção de mudas de penicilina (Alternanthera brasiliana (L.) Kuntze) via estaquia. Rev. Bras. Plantas Med. 16(3), 644-648. Doi: 10.1590/1983-084x/12 098

Yadav, A. K., S. Singh, D. Dhyani, and P.S. Ahuja. 2011. A review on the improvement of stevia [Stevia rebaudiana (Bertoni)]. Can. J. Plant Sci., 91(1), 1-27. Doi: 10.4141/cjps10086

Zuffellato-Ribas, K.C. and J.D. Rodrigues. 2001. Estaquia: uma abordagem dos principais aspectos fisiologicos. Editora UFPR, Curitiba-PR, Brazil. 